\title{
The Microbiome and Mental Health: Looking Back, Moving Forward with Lessons from Allergic Diseases
}

\author{
Alan C. Logan ${ }^{1,2}$, Felice N. Jacka $a^{1,2,3,4,5,6}$, Jeffrey M. Craig ${ }^{1,7}$, Susan L. Prescott ${ }^{1,8}$ \\ IInternational Inflammation (in-FLAME) Network, Worldwide Universities Network (WUN), ${ }^{2}$ International Society for Nutritional Psychiatry \\ Research (ISNPR), ${ }^{3}$ The Centre for Innovation in Mental and Physical Health and Clinical Treatment, School of Medicine, Deakin University, \\ Geelong, ${ }^{4}$ Centre for Adolescent Health, Murdoch Children's Research Institute, Melbourne, ${ }^{5}$ Department of Psychiatry, University of \\ Melbourne, Melbourne, ${ }^{6}$ Black Dog Institute, Sydney, 'Group of Early Life Epigenetics, Department of Paediatrics, Murdoch Children's \\ Research Institute, University of Melbourne, Melbourne, ${ }^{8}$ School of Paediatrics and Child Health, University of Western Australia, Perth, \\ Australia
}

\begin{abstract}
Relationships between gastrointestinal viscera and human emotions have been documented by virtually all medical traditions known to date. The focus on this relationship has waxed and waned through the centuries, with noted surges in interest driven by cultural forces. Here we explore some of this history and the emerging trends in experimental and clinical research. In particular, we pay specific attention to how the hygiene hypothesis and emerging research on traditional dietary patterns has helped re-ignite interest in the use of microbes to support mental health. At present, the application of microbes and their structural parts as a means to positively influence mental health is an area filled with promise. However, there are many limitations within this new paradigm shift in neuropsychiatry. Impediments that could block translation of encouraging experimental studies include environmental forces that work toward dysbiosis, perhaps none more important than westernized dietary patterns. On the other hand, it is likely that specific dietary choices may amplify the value of future microbial-based therapeutics. Pre-clinical and clinical research involving microbiota and allergic disorders has predated recent work in psychiatry, an early start that provides valuable lessons. The microbiome is intimately connected to diet, nutrition, and other lifestyle variables; microbial-based psychopharmacology will need to consider this contextual application, otherwise the ceiling of clinical expectations will likely need to be lowered.
\end{abstract}

KEY WORDS: Depression; Anxiety; Diet; Human microbiome; Microbiota; Allergy and Immunology.

\section{INTRODUCTION}

There is little doubt that the prevention and treatment of conditions associated with mental health is a critical issue of our time. ${ }^{1,2)}$ Mental, neurological, and substance abuse disorders now represent a substantial proportion of the world's disease burden. ${ }^{3,4)}$ In particular, major depressive disorder (MDD) and anxiety disorders are debilitating illnesses that are on a trajectory toward leadership within global burden of disease rankings. ${ }^{3)}$

Mental health is described by the World Health Organization (WHO) not by the absence of disorder per $s e$, but the ability of an individual to reach their potential,

Received: August 31, 2015 / Accepted: November 5, 2015

Address for correspondence: Felice N. Jacka, PhD

IMPACT SRC, School of Medicine, Deakin University, PO Box 281, Geelong, VIC 3220, Australia

Fax: +61-3-4215-3491

E-mail: felicejacka@gmail.com cope with normal stressors, work productively, and make contributions to the community. ${ }^{5)}$ Both MDD and subthreshold/subsyndromal conditions that do not meet full diagnostic criteria are important considerations in the risk of other non-communicable diseases (NCDs) such as Type II diabetes, cardiovascular disease, obesity and dementia. ${ }^{6-10)}$ Further, the WHO rightfully maintains that without mental health, there can be no true physical health. ${ }^{11)}$ However, the opposite is also true; chronic 'physical' NCDs can compromise mental health. ${ }^{12,13)}$

There is little evidence to suggest that, in comparison to previous generations, recent cohorts in westernized nations are better off psychologically. Recent studies suggest just the opposite. ${ }^{14-16)}$ Pharmacological innovation in treatments for mental illness has lagged in the last several decades, and it is widely recognized that alternate approaches beyond the monoamine hypothesis-deficits in noradrenergic and serotonergic systems - are necessary. ${ }^{17)}$

Despite their many differences, NCDs are most often

(a) This is an Open-Access article distributed under the terms of the Creative Commons Attribution Non-Commercial License (http://creativecommons.org/licenses/by-nc/4.0) which permits unrestricted non-commercial use, distribution, and reproduction in any medium, provided the original work is properly cited 
united by the common threads of immune dysfunction and chronic, low-grade inflammation. ${ }^{18-20)}$ Depression, for example, is commonly associated with elevations in C-reactive protein, inflammatory cytokines and oxidative stress. Inflammation-induced consequences in the central nervous system can include altered neurotransmission. ${ }^{21-24)}$ As we will describe later, this may explain, in part, the high levels of overlap between NCDs such as allergic diseases and mental disorders.

The complex interplay between dietary patterns, psychological stress, environmental exposures such as pollutants, and lifestyle variables such as circadian disruptions and sedentary behavior, are of clear relevance to most, if not all NCDs. These factors can contribute to, or temper, the low-grade inflammation and biological dysregulations associated with depression and other NCDs. ${ }^{25)}$ This might be particularly true when the exposure/experience occurs in early life. ${ }^{26,27)}$

It is also increasingly recognized that these environmental factors can impact upon human-associated microbiota (and their genetic contributions, including their non-living structural components; i.e. the microbiome). ${ }^{28-31)}$ The microbiome, in turn, may strongly influence overall health and the daily expression of our own genes. ${ }^{32,33)}$ Indeed, the recently observed relationships between anxiety and/or depressive symptoms and various dietary patterns, such as the westernized or traditional dietary patterns, ${ }^{34,35)}$ may be, at least partly, explained by the impact of diet and its components on the microbiome. ${ }^{36)}$ From an optimistic perspective, the determinants of immune system priming and resiliency against mental disorders may be modifiable by lifestyle changes, nutrition and psychopharmacetical interventions that target the microbiome.

The concept that diet can impact on human microbial ecosystems, which can in turn influence mental health, is the focus of the current review. This topic now gives rise to headline stories in popular magazines ${ }^{37)}$ and news pieces in leading journals. ${ }^{38-40)}$ However, amid the enthusiasm, it is helpful to review the history and identify pitfalls surrounding the growing focus on the microbiome and brain health. In particular, nearly two decades of research from the realm of allergy and asthma (combined here as allergy related diseases) has provided signposts for neuropsychiatry, and long-term intervention studies have already begun to highlight the shortcomings of viewing microbes as a stand-alone technological solution.

\section{HISTORICAL ASPECTS}

"So early as Hippocrates, the abdominal viscera were regarded as the principal seats of disease in mania and melancholia. This doctrine has been, at various times, forgotten and revived from that period to the present moment, according as circumstances have occurred to influence the minds of the medical practitioners and as the opinions of the metaphysical or physical pathologists have prevailed."

David Uwins, MD,

Physician to the City of London Dispensary, $1818^{41)}$

By the beginning of the 20th century, microbes were considered to be directly (and indirectly via their by-products released within the intestinal lumen) involved in various culturally-mediated diagnoses such as melancholic outlook, malaise, neurasthenia, and what were known as 'the neuroses'. Preliminary reports suggested that the administration of beneficial microbes could be helpful in cases of depression ${ }^{42,43)}$ and dietary alterations, especially macronutrients, were part of mainstream discussions concerning ways to manipulate intestinal microbiota for health. ${ }^{44)}$

For example, manipulating dietary protein and carbohydrate in animals could induce changes in behavior with associated changes in the microbiota. The behavioral changes were attributed to a combination of both direct macronutrient influences on mood, and the indirect ability of foods to shift the production of mood-altering microbial byproducts. ${ }^{45)}$ Psychological stress was also part of the theoretical considerations as physicians speculated on potential pathways in chronic melancholia:

"Disturbing the sympathetic and autonomic nervous centers as to result in disturbance of the digestive apparatus, such disturbance may lead to the development of an excess of certain bacteria... we need not even assume it is always the same bacterium which gives rise to symptoms like those of melancholia. Various antibodies and various metabolic by-products called out by the presence of bacterial enzymes, may be the particular poisons causing the 'cough' known as melancholia."

Robert T. Morris, MD, 1919 $9^{46)}$

As discussed in detail elsewhere, ${ }^{47)}$ some of the fledgling scientific findings during the 'bacterio-mania' of the early 20th century were groundbreaking. However, the science of so-called intestinal toxemia was rudimentary, and largely teetered on the theoretical; risky intestinal surgeries were performed to "rid" the body of its toxic reservoir, and the commercially lucrative 'microbial product' cart was placed before the proverbial horse. ${ }^{47)}$ This first 
wave of serious interest in microbiota and mental health spanned from approximately 1900-1930, and left a legacy of unnecessary surgeries, useless products and unwarranted fears concerning frequency of what constituted normal bowel movements.

\section{TOPIC IN EXILE}

The end of the 'intestinal toxemia' era coincided with the dawn of the antibiotic era, ${ }^{48)}$ one that demonstrated clear, life-saving results based on simple intervention. Antibiotics shifted scientific thought back toward pathogens. Co-incident with antibiotic development, the cultural shift in mid-20th century westernized mental health care was also heavily weighted toward top-down (emotion to viscera) psychosomatics and scientifically unverifiable Freudian influences. ${ }^{49,50)}$ Then, with a growing focus on biological psychiatry, the monoamine theories of depression in the 1950-60s dominated drug development. $^{51)}$

During this period even noteworthy microbiological findings were approached with trepidation. In 1962, one of the most highly-respected microbiologists in mid-century America, Dubos and Schaedler ${ }^{52)}$ reported remarkable findings concerning the ways in which diet, antimicrobials and stress could influence growth, susceptibility to infections, and the lethality of systemic endotoxin -all in concert with changes to intestinal microbiota. However, they first had to contend with the historical legacy of intestinal toxemia:

"The findings we wish to report here cannot help evoking memories of a quaint bygone scientific era. They call to mind Metchnikoff's assertions half a century ago that most of the ills of old age arise from intestinal intoxication, and that lactobacilli play a useful role in man and animals by antagonizing the noxious components of the intestinal flora. Today, Metchnikoff's imaginings are of interest only to a few historians, health cranks, and the manufacturers of yoghurt and acidophilus milk." ${ }^{52)}$

Through the 1960s and early 1970s, Dubos and his colleagues published dozens of experimental studies implicating the intestinal microbiota in multiple aspects of health. Described elsewhere in detail, ${ }^{53)}$ his studies focused on microbiota, diet, and other environmental variables. For example, Lee and Dubos ${ }^{54)}$ reported that when female specific-pathogen-free mice are fed low quality protein during the perinatal period, the brain content of dopamine and norepinephrine in offspring is diminished. They concluded that "Metchnikoff's concepts of intestinal intoxication may have some factual basis after all" and that they were "inclined to believe that the usual intestinal flora is an expression of man's total environment, and that its control may turn out to have as profound effects on the well-being of human infants and adults as it has on the growth of mice and farm animals". 52)

Studies by Dubos and his colleagues went largely unreferenced and the concept of beneficial microbes for mental well-being was certainly a neglected subject through the remainder of the 20th century. The proposition that the intestinal microbes are collectively a distinct $\operatorname{organ}^{55)}$ was given little credence. Notions of a connection between the intestinal microbiota, the integrity of the intestinal lining, and the systemic influence of microbial toxins on mental/neurological health (save for advanced pathogenic conditions; e.g., hepatic encephalopathy) were considered to defy the prevailing logic. ${ }^{47}$

\section{LESSONS FROM ALLERGIC DISORDERS, HYGIENE HYPOTHESIS}

"Psychoimmunologic research has often had a unidirectional focus from the mind to the immune system-e.g., immune dysfunction in individuals with and without psychosocial stress...the field should also consider the other direction for central nervous-immune system interactions, i.e., possible affective dysfunction in individuals from additive or synergistic immunological events."

Iris R. Bell, MD, et al. $1991^{56)}$

As the 20th century drew to a close, one avenue of intestinal microbiota and health research did remain open: allergy related diseases. Much of this field was built upon the hygiene and microbial deprivation hypotheses. Jointly they proposed that the global rise in allergic disease could be related to diminished opportunity for early life exposure to pathogenic microbe exposure and overall microbial diversity via increased hygiene, antibiotics, smaller family sizes, altered dietary patterns and other environmental factors. ${ }^{57-59)}$

Allergy and asthma research circa 2000 promoted a focus on the modern intersection between diet, external environment, and microbes. ${ }^{59-64)}$ Omega-3 fatty acids were posited to be important for prevention and treatment of allergy-related diseases. ${ }^{65)}$ Lactic acid bacteria and fermented foods were proposed to attenuate allergic disease via their influence on the immune system and $\mathrm{T}$ helper cell 1 and 2 (Th1/2) balance, ${ }^{66-68)}$ although there was no specific connection to mental or cognitive health. 
However, the overlaps between allergic disorders, chronic fatigue/chronic fatigue syndrome (CFS), depression and anxiety were noted to be extraordinarily high. ${ }^{56)}$ Subsequently, in 2002, a new perspective on the intersection between allergic disorders (and other immune abnormalities) and mental health led to an entirely new proposal - that beneficial microbes may play a role in neuro-cognitive functioning and behavioral disturbances via immune and other pathways. ${ }^{69)}$

Pioneering research around that time (using culture techniques) had already connected certain fecal microbial communities with neurological and cognitive deficits in fatigue and functional syndromes. ${ }^{70)}$ It had also been shown experimentally that orally administered Campylobacter jejuni (without overt immune activation) produces anxiogenic effects and activation of visceral sensory nuclei in the brainstem. This suggested that even in the absence of major immune shifts, autonomic, neuroendocrine and behavioral responses to miniscule amounts of gut bacteria were possible. ${ }^{71)}$ The vagus nerve was at least one pathway (but not the only route) whereby information concerning microbiota could be transmitted from the gut to the brain. ${ }^{72)}$

In 2001, a landmark study showed that very low levels of endotoxin in the blood can provoke cytokine release, alter cognition, and diminish mental outlook in humans. ${ }^{73)}$ And so it became theoretically realistic that there would be mental health consequences if the intestinal barrier was compromised. In popular writing, the description for this state of increased intestinal permeability (IP) was 'leaky gut'. ${ }^{\text {74) }}$ Since the largest reservoir of microbial endotoxin (lipopolysaccharide [LPS] endoxin in particular) is within the intestinal tract, this research opened the door to the mood-related consequences of IP.

Currently IP is under increased scrutiny as a key contributor in the causal pathways to chronic conditions such as asthma, ${ }^{75)}$ allergies, ${ }^{76)}$ depression and CFS. ${ }^{77,78)} \mathrm{IP}$ is al- so associated with alcohol use disorder, ${ }^{79)}$ obesity, ${ }^{80,81)}$ fibromyalgia, ${ }^{82)}$ extremes of exercise, ${ }^{83)}$ and psychological stress. ${ }^{84)}$ Experimentally, an increased LPS burden can increase toll-like receptor activation in the brain, which in turn can increase central nervous system inflammatory mediators and oxidative stress. ${ }^{85)}$ The dietary influences on IP are discussed in more detail below.

Adding to the interest in beneficial microbes for mental health, novel probiotic studies began to emerge in the early 2000s. Using experimental models, researchers showed that probiotics can benefit intestinal barrier function. ${ }^{86)}$ Other groups showed that oral probiotics can influence systemic markers of immune activation and oxidative stress in humans. ${ }^{87,88)}$ These studies provided further theoretical possibilities that beneficial microbes could be systemic mediators of neurological effect. Additional potential mechanisms include direct and indirect effects on neurotransmitter/neuropeptide production, enhancement of nutritional status, and more direct bacteria-to-brain communication (Fig. 1). ${ }^{69,89)}$

An influential 2004 study reported that gene expression of a primary nerve growth factor, brain derived neurotrophic factor (BDNF), was lower in the hippocampus and the cortex of germ-free (GF) animals compared with conventionally-raised specific pathogen-free animals. ${ }^{90)}$ As BDNF plays a critical role in the plasticity of nerves throughout life, this indicates that commensal microbes are capable of influencing brain structure and function. The study also showed that GF mice had enhanced hypothalamic-pituitary-adrenal axis activity following acute stress, demonstrating that microbiota are involved in programming the stress response. An overlooked, but no less important study also showed that conventionally-raised animals (vs. GF) have higher levels of histamine in the hypothalamus. $^{91)}$ Today, the importance of histamine, BDNF and other nerve growth factors are central in discussions of brain health. ${ }^{92,93)}$

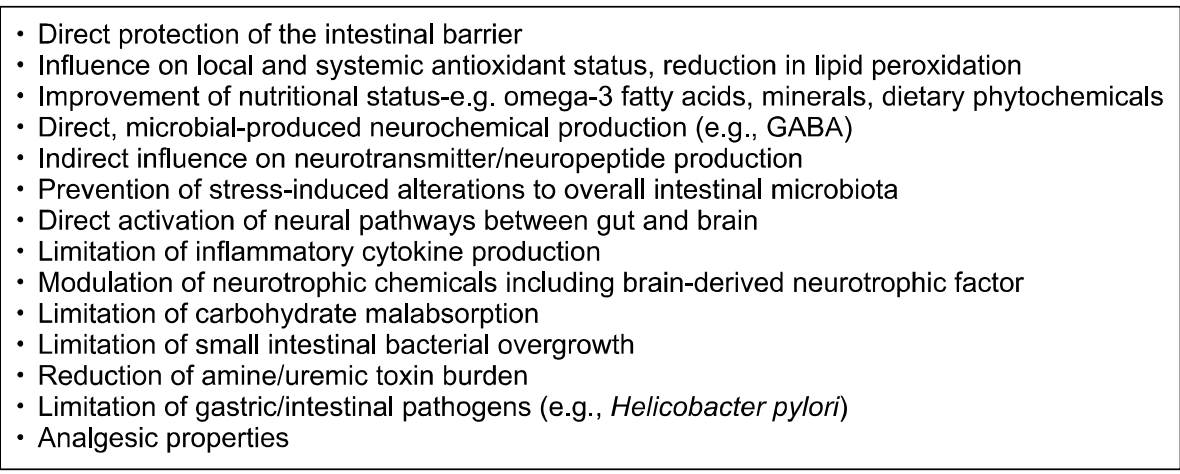

- Direct protection of the intestinal barrier

- Influence on local and systemic antioxidant status, reduction in lipid peroxidation

- Direct, microbial-produced neurochemical production (e.g., GABA)

- Indirect influence on neurotransmitter/neuropeptide production

- Prevention of stress-induced alterations to overall intestinal microbiota

- Direct activation of neural pathways between gut and brain

- Limitation of inflammatory cytokine production

- Limitation of carbohydrate malabsorption

- Reduction of amine/uremic toxin burden

- Limitation of gastric/intestinal pathogens (e.g., Helicobacter pylori)

- Analgesic properties

Fig. 1. Beneficial microbes for fatigue and depression; originally proposed pathway. Adapted from references 57,78 , and 225 . 


\section{ADVANCES IN RESEARCH}

In recent years it has become even more clear that there are bi-directional relationships between depression and/or anxiety disorders and the subsequent risk of asthma, and vice vers $a^{94,95)}$ Indeed, maternal depression and anxiety in pregnancy may increase the risk of allergic disorders in offspring. ${ }^{96)}$ Despite the heterogeneity of CFS physiology, evidence now indicates that a shift to a Th2 immune response (and away from Th1) is most characteristic of the syndrome. Interestingly, allergies in general, and allergic rhinitis in particular, have been noted to predate the subsequent onset of CFS. ${ }^{97)}$ The multi-system complexity of CFS has made this a proving ground for understanding the relevancy of the immune system to mental health, allergies, so-called functional gastrointestinal disorders (e.g., irritable bowel syndrome) and microbiota.

Sequencing technologies and inventories of the $16 \mathrm{~S}$ rRNA gene have overcome some of the drawbacks of culture-only techniques, and allowed for detailed characterization of microbial ecosystems in intestinal, oral and cutaneous samples. There is mounting evidence that patients with depression $^{98,99)}$ or $\mathrm{CFS}^{100,101)}$ show distinctions in their intestinal microbiota. Moreover, emerging research continues to show that diminished microbial diversity in early life can place an individual on a trajectory toward increased risk of allergic diseases. ${ }^{102,103)}$ Specific changes in fecal microbiota may not necessarily be the same throughout NCDs, however the new findings help to further clarify the ways in which the common NCD threads of immune dysregulation and chronic low-grade inflammation could impact upon, and be affected by, microbial factors.

As for research in dietary patterns, the evidence continues to grow in both the realms of allergic disorders and mental health. From a temporal perspective, the study of nutritional factors in mental health, especially dietary patterns, is a more recent phenomenon that has risen in concert with the gut-brain-microbiota research. A decade ago, diet and nutrition were not mainstream in neuropsychiatry conversations. Even in allergy, the focus of nutrition was minimal prior to the global rise in frequency of food allergy. ${ }^{104)}$ This has now shifted the spotlight to early gastrointestinal events in the breakdown of oral tolerance-a factor that may be equally relevant to the rising rates of neurodevelopmental disorders. Today, there seems little doubt that overall diet and specific nutrients are of critical importance in optimal development and mental health. ${ }^{23)}$

While many questions remain, the general themes in mental ill-health, allergy and other inflammatory dis- orders are quite similar, including their environmental risk factors. Dietary patterns that more closely resemble traditional, less-processed diets (e.g., Mediterranean model) appear protective against the risk of allergies, asthma, depression and other NCDs that have been associated with dysbiosis and immune dysregulation. On the other hand, higher consumption of fast foods and highly-processed foods - those that more closely resemble what is now known as the 'westernized' dietary pattern - have been associated with a higher risk of the aforementioned conditions. ${ }^{19,20,105,106)}$ These conditions also share early life risk factors, many of which determine life-long propensity to inflammation. ${ }^{107)}$ These are increasingly viewed from a 'developmental origins' perspective, particularly as epigenetic mechanisms are becoming better understood (as discussed below). Therefore, early disruptions in microbial diversity and their linkage to allergic outcomes and neurobehavioral disorders ${ }^{102,103,108)}$ adds to our understanding of the early life origins of immune dysregulation as an antecedent event in many NCDs.

\section{MICROBIOTA: RODENT STUDIES}

The emerging potential of microbial manipulation for mental health rests upon groundbreaking studies involving rodents. Notwithstanding the multiple limitations concerning the application of rodent studies to the human condition in general, ${ }^{109)}$ and human microbiota and complex mental health in particular, ${ }^{110-112)}$ these studies have certainly proved insightful and established a much-needed foundation that includes potential mechanisms.

The vagus nerve is a confirmed conduit for promoting anxious behavior following induction of intestinal inflammation, and of anxiolysis following administration of a probiotic. ${ }^{113)}$ Probiotic supplementation to healthy animals reduces anxiety and depression-like behavior in various models of stress-induction. ${ }^{114)}$ Critically, behavioral changes are associated with changes in the expression of gamma-aminobutyric acid (GABA) receptors in areas of the brain governing emotion. Again, the vagus nerve appears to be the channel between beneficial microbes, behavior and brain chemistry. ${ }^{114)}$ Beneficial microbes are also known to suppress histamine signaling in allergy models. $^{115)}$

Another classic experimental model involves fecal microbial transfer. In GF BALB/c mice, a strain with known deficits in sociality and diligent risk assessment of the environment, ${ }^{116,117)}$ colonization with microbiota derived from more 'explorative' NIH Swiss mice changes the be- 
havior of the $\mathrm{BALB} / \mathrm{c}$ recipients - with more explorative behavior in the weeks following. On the other hand, when NIH Swiss mice are colonized with the BALB/c microbiota, they display greater hesitancy. ${ }^{118)}$ Such behaviors are indicative of both anxiety and in situ risk taking. Animal research also shows that probiotic pretreatment prevents decreases in hippocampal neurogenesis typically induced by stress, and favorably influences the expression of hypothalamic genes involved in synaptic plasticity. Interestingly, these effects in the brain are linked to the ability of the probiotic to mitigate stress-related IP. ${ }^{119)}$

Upregulation of oxytocin provides another novel pathway for the systemic action of probiotics and the microbiota in general. ${ }^{120)}$ This neuropeptide hormone is connected to pair bonding, regulation of circadian rhythms, ${ }^{121,122)}$ prevention of $\mathrm{IP}^{123)}$ and is emerging as a significant target of drug development for the treatment of psychiatric disorders. ${ }^{124)}$ Interestingly, since oxytocin can also modulate risk taking and the saliency of social cues, ${ }^{125)}$ this might explain probiotic/fecal transfer-induced risk taking in otherwise risk-averse, anxious mice.

Further highlighting the links between inflammation, metabolic disease and the brain, faecal transplants in murine models of obesity also illustrate the microbiota-dietary connection. When lean, healthy mice (consuming standard laboratory chow) are the recipients of fecal microbiota derived from donor mice raised on a high-fat diet, significant behavioral changes are observed. These include signs of anxious behavior, cognitive difficulties and stereotypical, repetitious behavior. ${ }^{126)}$ Moreover, the production of short-chain fatty acids (e.g., butyric acid) by microbial activity on dietary fiber may play a key role in the development and function of microglia. ${ }^{127)}$ Short chain fatty acids derived from the colon may be able to pass the blood-brain barrier and influence transcellular neurotransmitter cycles. ${ }^{128)}$ Since normal-functioning microglia are essential in striking the optimal balance between host defense and synaptic plasticity (over-activation has been linked to neuroinflammation), the ways in which environmental factors influence both gut microbiota and neurochemistry are probably not yet fully realized.

\section{BENEFICIAL MICROBES: HUMAN RESEARCH}

There have been a number of human intervention studies involving beneficial microbes and mood-related outcomes. ${ }^{129-137)}$ To the best of our knowledge, there has yet to be an intervention study involving microbes and patients with MDD or anxiety disorders. However, the benefits observed in the available clinical studies suggest that a movement toward trials involving patients with depression, anxiety, or subsyndromal disorders is warranted. Highlights of human research are presented in Table 1. In our opinion, this provides room for optimism concerning the potential value of beneficial microbes.

These studies are bolstered by the experimental studies

Table 1. Select human studies involving probiotics

\begin{tabular}{|c|c|c|c|c|}
\hline & Subjects/Condition & Beneficial microbe(s) & Duration & Beneficial outcome \\
\hline$(131)$ & Healthy adults $(n=124)$ & Lactobacillus casei Shirota & 3 Weeks & $\begin{array}{l}\text { Those in the bottom } 1 / 3 \text { of the group initial scores on } \\
\text { POMS reported feeling happier and less depressed }\end{array}$ \\
\hline (130) & Laryngeal cancer $(n=20)$ & $\begin{array}{l}\text { Clostridium butyricum } \\
\text { Unspecified strain }\end{array}$ & $\begin{array}{l}2 \text { Weeks, } \\
\text { pre-surgery }\end{array}$ & $\begin{array}{l}\text { Lowered serum corticotropin-releasing factor, heart rate; } \\
\text { reduced HAS scores pre-surgery }\end{array}$ \\
\hline$(132)$ & Chronic fatigue $(n=39)$ & L. casei Shirota & 8 Weeks & Improved scores on BAI vs. baseline \\
\hline$(135)$ & Healthy adults $(n=44)$ & $\begin{array}{l}\text { L. gasseri OLL2809 } \\
\text { heat inactivated }\end{array}$ & 4 Weeks & Decreased tension-anxiety on the POMS \\
\hline$(137)$ & Healthy adults $(n=40)$ & $\begin{array}{l}\text { Bifidobacterium bifidum W23 } \\
\text { B. lactis W52 } \\
\text { L. acidophilus W37 } \\
\text { L. brevis W63 } \\
\text { L. casei W56 } \\
\text { L. salivarius W24 } \\
\text { L. lactis W19/W58 }\end{array}$ & 4 Weeks & $\begin{array}{l}\text { Reduced self-reported cognitive reactivity to sad mood; } \\
\text { reduced aggressive/ruminative thoughts. Measured via } \\
\text { Leiden Index of Depression Sensitivity }\end{array}$ \\
\hline$(133)$ & Healthy adults $(n=55)$ & $\begin{array}{l}\text { L. helveticus } \mathrm{R} 0052 \\
\text { B. longum R0175 }\end{array}$ & 4 Weeks & $\begin{array}{l}\text { Lower global severity index on the Hopkins Symptom } \\
\text { Checklist 90; Improved depression anger-hostility and } \\
\text { somatization; lower anxiety on the HADS }\end{array}$ \\
\hline $\begin{array}{l}(136) । \\
(n=75\end{array}$ & $\begin{array}{l}\text { Infants with atopy risk } \\
\text { 5) }\end{array}$ & L. rhamnosus GG & $\begin{array}{l}24 \text { Weeks } \\
\text { post-birth }\end{array}$ & $\begin{array}{l}\text { Physician-diagnosed attention-deficit hyperactivity or } \\
\text { Asperger syndrome (ICD-10 criteria at age } 13 \text { years) is } \\
\text { lower }\end{array}$ \\
\hline
\end{tabular}

POMS, the Profile of Mood States; HAS, Hamilton Anxiety Scale; BAI, Beck Anxiety Inventory; HADS, Hospital Anxiety and Depression Scale; ICD-10, International Classification of Diseases 10th revision. 
described earlier, and by other human studies that indicate value of microbes and microbial-transformed foods in objective markers of stress physiology, ${ }^{138)}$ brain activation, ${ }^{139)}$ and 'quality of life' improvements in other medical conditions. ${ }^{140-142)}$ On the other hand, the extremely limited nature of the current body of human research should be recognized. In addition to the absence of specific mental health disorders, the small sample size of the published studies mean that the field can only be described as preliminary.

\section{ODYSSEY TO TRANSLATION-DIET AS THE COMPASS}

Although the last word is far from written, it is clear that dietary patterns and specific combinations of nutrients such as omega-3 fatty acids, zinc, magnesium and plant phytochemicals are of relevance to depression and other mental disorders. ${ }^{143)}$ Epidemiological studies have reported that more traditional dietary patterns are associated with good mental health and lowered risk of depression. ${ }^{14-148)}$ Short-term intervention studies show that traditional dietary patterns can positively influence mental outlook, cognition and chronic fatigue. ${ }^{149-151)}$

As the idea of targeting the microbiome for mental health begins its long trek toward translation, it would seem obvious that diet may be the "rate limiting step" in the chain reaction that otherwise might allow microbes to work toward long-term mental health. At virtually all junctures of the known and theoretical mechanistic pathways by which microbes could influence brain health (Fig. 1), diet is an undeniable focal point. Perhaps the easiest way to illustrate this is to examine the consequences of maintaining a westernized dietary pattern.

The modern westernized diet is distinct from traditional, ancestral dietary patterns in two fundamental ways. Firstly, by its much higher content of ultra-processed foods, added fats, sugar and sodium. Secondly, by what it excludes - relatively unprocessed plant foods, fermented foods, phytochemical-rich foods, fiber, and fats that are embedded naturally within foods (e.g., unprocessed meats, fish). The available evidence from communities who still maintain traditional (relatively non-western) lifestyles demonstrates that, among other environmental variables, the avoidance of a westernized diet and inclusion of traditional foods is a pathway to diversity and species richness of intestinal microbiota. ${ }^{152-157)}$ While researchers do not have a complete understanding of what constitutes a healthy intestinal microbiome, a generalized finding is that diversity may prevent metabolic dysregulation and favor health promotion. ${ }^{158,159)}$

Moreover, once a westernized dietary pattern is in place, it can be associated with sub-optimal intake (if not overt deficiencies) of essential fatty acids, vitamins and minerals. ${ }^{160)}$ Given the high fructose and sodium, ${ }^{161)}$ the dietary advanced glycation endproducts, and food additives that are consumed via processed foods, ${ }^{162,163)}$ together with inadequate omega- $3,{ }^{164)}$ excess alcohol consumption $^{165)}$ and low levels of vitamin $\mathrm{D}^{166,167)}$-each individually associated with marked shifts in the intestinal microbiota - the implications of dietary patterns in relation to the microbiome are clear.

Since the western diet is relatively devoid of deeply-colored fruits, vegetables and other plant-derived culinary items (e.g., turmeric, ginger, seaweeds, purslane, wasabi, Brassica-family sprouts, and regional spices) this represents a loss of complex phytochemicals that would otherwise make their way into the gastrointestinal tract. These phytochemicals play crucial roles in support of the antioxidant defense system, and in their ability to reduce the low-grade inflammation. In experimental studies, dietary phytochemicals from turmeric, apples, grapes, plums, blueberries and cherries (to cite only a few examples) can improve behavioral aspects of stress, anxiety and depression. ${ }^{168-171)}$

It is interesting to note that dietary items such as green tea, coffee, cocoa, curcumin, and other polyhenol-rich foods associated with fatigue reduction, positive mood and lowered risk of depression in humans ${ }^{172-175)}$ can also influence the growth of beneficial bacteria, and/or prevent dysbiosis in pre-clinical settings. ${ }^{176-179)}$ The transformation and structural alteration of many dietary phytochemicals by intestinal microbes may determine the extent of their benefits in the brain. ${ }^{180)}$ Remarkably, it also appears that microbially-transformed phytochemicals (e.g., quercetin after it has been subjected to fermentation) can modify the gut microbiota in ways that are considered healthy (i.e., growth of bifidobacteria and decrease in the ratio of Firmicutes to Bacteroidetes). ${ }^{181)}$

The Westernized dietary pattern also appears to play a central role in provoking IP and its systemic inflammation-based consequences. ${ }^{182)}$ However, phytochemical-rich foods and beverages may be able to prevent the typical elevations in circulating endotoxin when co-consumed with western dietary choices. ${ }^{183)}$ In experimental models, various phytochemicals have been shown to protect the intestinal barrier and prevent IP; these include but are not limited to curcumin, green tea catechins, quercetin 
and resveratrol. $^{184-186)}$

In addition, omega-3 fatty acids may play a particularly important role in preventing IP. Specifically, it is an increase in tissue omega-3 levels that appears to lead to a beneficial cascade of events - via higher intestinal alkaline phosphatase - that include modification of gut microbiota, lower LPS production, and decreased IP. ${ }^{187)}$ This is notable because tissue omega-3 levels may be low in depression, and omega-3-based interventions have been shown to have clinically-meaningful value in treatment and prevention of mood and anxiety disorders. ${ }^{188)}$ There is also preliminary evidence suggesting that omega-3 fatty acids may reduce the risk of infant sensitization to foods such as egg. ${ }^{189)}$ Indeed, the westernization of dietary patterns typically includes marked increases in omega-6 rich vegetable oils; this may translate into lower relative tissue concentrations of omega-3 fats. ${ }^{190)}$

\section{SIMPLE FOOD, SINGLE NUTRIENT HIGHLIGHTS COMPLEXITY}

Further identification of the importance of dietary constituents vis a vis microbiota and mental health can be found in the experimental research on honey. It is high in phytochemicals, particularly those in the phenolic acid and flavonoid families. ${ }^{191)}$ Several pre-clinical studies indicate that honey has antidepressant and anxiolytic properties. ${ }^{192,193)}$ Remarkably, honey flavonoids have been shown to show significantly inhibit the release of pro-inflammatory cytokines such as tumor necrosis factor alpha and interleukin-1 beta from microglia when they are stimulated by LPS. ${ }^{194)}$ It is no less noteworthy that honey and its constituents appear to have a beneficial influence on intestinal microbiota. ${ }^{195,196)}$

Dietary magnesium (found within deeply colored green vegetables) represents another simplified example of the way in which nutrition cannot be isolated from microbe-mental health conversations. Several studies have shown that low magnesium (and/or low dietary intake) is associated with depressive symptoms and anxiety. ${ }^{197)}$ In experimental studies, low dietary magnesium intake alters the microbiota, which in turn is linked to inflammatory cytokine release in the brain and signs of anxiety and depressive behavior. ${ }^{198,199)}$ Much like honey, magnesium also inhibits the inflammatory consequences of LPS-stimulated microglia. $^{200)}$

\section{EPIGENETICS AND THE FIRST 1,000 DAYS}

Epigenetics includes the study of the ways in which alterations in chromatin structure can influence gene expression via mechanisms that do not involve changes to the primary DNA sequence. Two of the best-studied epigenetic signals include DNA methylation and histone modification. Despite the complexity of epigenetics, it is becoming increasingly clear that epigenetic regulation can play crucial roles in the fate of the functioning of the immune system, and that bio-environmental factors - including diet and microbial-generated products that are determined by dietary choices (such as butryrate)-are central to epigenetic modifications that could orient immune programming toward health. ${ }^{201)}$

There is much hope in early interventions that could be directed toward allergic disease and mental disorders. Aforementioned dietary phytochemicals such as quercetin, curcumin and catechins are known epigenetic modifiers. ${ }^{202)}$ It is likely that the greatest impact of microbe-based psychopharmacology (see "psychobiotics" below), including those that could influence epigenetic signals, will be evident in early life. Extensive international research supports the developmental origins of health and disease (DOHaD) construct, which suggests that early life environmental experiences, particularly those encountered in the first two years of life, predict subsequent NCD risk. ${ }^{203)}$

The quality of perinatal nutrition has been associated with subsequent mental health outcomes. ${ }^{204)}$ Moreover, long-term follow-up of a project which was originally initiated to examine early-life probiotic intervention to prevent allergy, has indicated there may be value in the prevention of brain-related conditions (attention-deficit hyperactivity and Asperger syndrome) at 13 years of age. ${ }^{135)}$ Epigenetic mechanisms are an important part of the $\mathrm{DOHaD}$ discussions, especially as they relate to allergic and mental disorders. ${ }^{205,206)}$

It is possible that targeting the gut microbiome early in life with microbial-based products could help to overcome the environmental forces that might otherwise set up epigenetic signals that direct toward increased NCD risk. One such environmental factor includes maternal and early-life antibiotic use. ${ }^{207)}$ Although early-life antimicrobial use has been the subject of much research in allergic disease (and more recently, obesity), ${ }^{208)}$ less is known concerning subsequent mental health. It is difficult to paint all antimicrobials with the same brush; however, some experimental studies suggest that they can induce behavioral changes, including anxiety. ${ }^{209-211)}$ 


\section{PSYCHOBIOTICS IN CONTEXT}

'Psychobiotics' is a recently-coined term referring to beneficial microbes that may provide value in cases of diagnosed mental disorders. Introduced in 2013, the term refers to "a live microorganism that, when ingested in adequate amounts, produces a health benefit in patients suffering from psychiatric illness". ${ }^{212}$ This definition is a good fit for commercially-driven product development wherein the microbes must be living and are intended for use specifically in cases of psychiatric illness.

The term psychobiotic, as currently defined, may be too narrow. Non-living microbes are excluded, as are microbial parts such as DNA. Yet, human subject research shows value of heat-inactivated microbes in mental health and allergic disorders; this may be via their influence on the immune system and markers of stress physiology ${ }^{134,213-216)}$ Moreover, the microbial components, even at the genetic level, have been shown to influence physiology. ${ }^{217,218)}$ Narrow views toward single (or a few) microbe solutions may neglect the microbial contexts and synergies that produced such startling preliminary research in the first place. One concern is that a focus on narrowly defined psychobiotics might cloud broad discussions of microbial ecosystems. Looking to the realm of post-hygiene hypothesis allergy research, it becomes plain to see that interventions with single (or select few) microbes have not always produced the desired outcomes over the long-term. ${ }^{\text {219-222) }}$

We can also look to emerging research concerning the microbiome and obesity as a way to highlight the inherent perils of microbial solutions viewed apart from environmental realities. In GF animal studies involving transfer of fecal material derived from lean and obese mice and/or human twins, there seems little doubt that an obesogenic microbiome can influence metabolism and energy storage. However, the ability to overcome this is diet-dependent. $^{223,224)}$ In other words, it may be difficult to realize long-term metabolic and immune benefits after obtaining a fecal transplant from a healthy donor, if default westernized dietary practices remain in place. ${ }^{31)}$

On the other hand, as mentioned above, many of food/ herbal-derived phytochemicals associated with mental health are also known to prevent dysbiosis. Research on microbes found in fermented foods and/or the action of microbes upon phytochemicals demonstrates that microbes could potentially influence mental health by virtue of their ability to transform the food. Transformation during fermentation could lead to novel therapeutics via newly- formed and/or more bioavailable phytochemical structures and peptides. ${ }^{225)}$

In a recent study involving over 700 young adults, it was reported that fermented food consumption was associated with less social anxiety, and specifically, among those with high in neuroticism scores, greater frequency of fermented food consumption was associated with fewer symptoms of social anxiety. ${ }^{226}$ Fermented food consumption is also associated with a lowered risk of developing allergic disorders in children. ${ }^{227)}$ In addition, the structural parts of heat-inactivated microbes (those associated with fermented foods) are also consumed, and these may also have far-reaching effects on intestinal ecosystems. ${ }^{228)}$ Beneficial microbes carried on/within fruits and vegetables might also influence the human immune system. $^{229)}$ Remarkably, very little is known concerning the microbes, both viable and non-viable, that are directly consumed as part of daily meals. ${ }^{230)}$

\section{CONCLUSIONS}

The microbial-mental health realm has a somewhat checkered past. At the beginning of the 20th century, major advances were making intestinal microbes part of mainstream discussions. In their own era, urinary indican and the identification of intestinal by-products (such as putrefactive amines), and the early reports of beneficial microbes (oral and commensal fecal transfer) for mental health were revolutionary. ${ }^{47)}$

Awareness of this history is, in our opinion, quite important. There are many parallels to be found in some of the unbridled enthusiasm with which microbial biotechnological solutions are proposed today. We must also begin to query the limitations and environmental contexts in which microbes are to be applied. Stress can induce systemic inflammation, and differing dietary patterns (low-fat vs. high-fat and westernized) can influence weight and body-fat storage, by mechanisms independent of intestinal microbiota. ${ }^{231,232)}$ Therefore, we must not be tempted to view complex NCDs as if they were Clostridium difficile infections where problem and microbial solution are more neatly defined.

Human mental health and allergic disorders, and other NCDs rooted in chronic low-grade inflammation, even in their early origins, are as complex as the microbial ecosystems from which these isolated microbes are removed. Thus, single-strain prevention strategies have many obstacles to overcome. From the treatment perspective, the odds of long-term, clinically-significant benefits of mi- 
crobe-based products would also seem slim if the environmental factors driving toward dysbiosis remain in place.

There are, however, reasons to suspect that supplementation with beneficial microbes can provide synergistic support to established mental health interventions. There is a generally good safety record of probiotics, even in children. ${ }^{233)}$ Given the gastrointestinal side-effects of prescription psychotropic medications, and the unknowns concerning their effect on human microbiomes, ${ }^{234)}$ supplementation with beneficial microbes, may provide important value.

The available evidence from allergic diseases concerning nutritional influences on epigenetic programming ${ }^{235}$ ) clearly indicates that a whole food dietary composition approach (vs. isolated nutrients) is far more likely to augment the clinical value of microbial psychopharmacology. With already well-documented collateral health benefits, ${ }^{236)}$ and emerging research demonstrating specific mental health value, ${ }^{226)}$ fermented foods represent a gateway to the discussion of healthy dietary patterns and the intestinal ecosystem. One of the most exciting, if not daunting, aspects of the microbiome revolution is that it forces an even more assiduous clinical consideration of the importance of healthy lifestyles.

\section{REFERENCES}

1. Weil TP. Insufficient dollars and qualified personnel to meet United States mental health needs. J Nerv Ment Dis 2015;203:233-240.

2. Goodman G, Gershwin ME, Bercovich D. Mars can wait: facing the challenges of our civilization. Isr Med Assoc J 2014; 16:744-747.

3. Whiteford HA, Ferrari AJ, Degenhardt L, Feigin V, Vos T. The global burden of mental, neurological and substance use disorders: an analysis from the Global Burden of Disease Study 2010. PLoS One 2015;10:e0116820.

4. Erskine HE, Moffitt TE, Copeland WE, Costello EJ, Ferrari AJ, Patton G, et al. A heavy burden on young minds: the global burden of mental and substance use disorders in children and youth. Psychol Med 2015;45:1551-1563.

5. World Health Organization. Mental health: strengthening our response. WHO Fact Sheet $N^{\circ} 220$, Aug 2014.

6. Rucci P, Gherardi S, Tansella M, Piccinelli M, Berardi D, Bisoffi G, et al. Subthreshold psychiatric disorders in primary care: prevalence and associated characteristics. $J$ Affect Disord 2003;76:171-181.

7. Goldney RD, Fisher LJ, Dal Grande E, Taylor AW. Subsyndromal depression: prevalence, use of health services and quality of life in an Australian population. Soc Psychiatry Psychiatr Epidemiol 2004;39:293-298.

8. Rodríguez MR, Nuevo R, Chatterji S, Ayuso-Mateos JL. Definitions and factors associated with subthreshold depressive conditions: a systematic review. BMC Psychiatry 2012;12:181.

9. Pietrzak RH, Kinley J, Afifi TO, Enns MW, Fawcett J, Sareen J. Subsyndromal depression in the United States: prevalence, course, and risk for incident psychiatric outcomes. Psychol Med 2013;43:1401-1414.

10. Sartorius N, Cimino L. The co-occurrence of diabetes and depression: an example of the worldwide epidemic of comorbidity of mental and physical illness. Ann Acad Med Singapore 2012;41:430-431.

11. Kolappa K, Henderson DC, Kishore SP. No physical health without mental health: lessons unlearned? Bull World Health Organ 2013;91:3-3A.

12. Gubata ME, Urban N, Cowan DN, Niebuhr DW. $A$ prospective study of physical fitness, obesity, and the subsequent risk of mental disorders among healthy young adults in army training. $J$ Psychosom Res 2013;75:43-48.

13. Sener U, Ucok K, Ulasli AM, Genc A, Karabacak H, Coban NF, et al. Evaluation of health-related physical fitness parameters and association analysis with depression, anxiety, and quality of life in patients with fibromyalgia. Int J Rheum Dis 2013. doi: 10.1111/1756-185X.12237. [Epub ahead of print]

14. Mojtabai R, Jorm AF. Trends in psychological distress, depressive episodes and mental health treatment-seeking in the United States: 2001-2012. J Affect Disord 2015;174: 556-561.

15. Keyes KM, Nicholson R, Kinley J, Raposo S, Stein MB, Goldner EM, et al. Age, period, and cohort effects in psychological distress in the United States and Canada. Am J Epidemiol 2014;179:1216-1227.

16. Twenge JM. Time period and birth cohort differences in depressive symptoms in the US, 1982-2013. Soc Indic Res 2015;121:437-454.

17. O'Brien PL, Thomas CP, Hodgkin D, Levit KR, Mark TL. The diminished pipeline for medications to treat mental health and substance use disorders. Psychiatr Serv 2014; 65:1433-1438.

18. Bosma-den Boer MM, van Wetten ML, Pruimboom L. Chronic inflammatory diseases are stimulated by current lifestyle: how diet, stress levels and medication prevent our body from recovering. Nutr Metab (Lond) 2012;9:32.

19. Guarner V, Rubio-Ruiz ME. Low-grade systemic inflammation connects aging, metabolic syndrome and cardiovascular disease. Interdiscip Top Gerontol 2015;40:99-106.

20. Prescott SL. Early-life environmental determinants of allergic diseases and the wider pandemic of inflammatory noncommunicable diseases. J Allergy Clin Immunol 2013;131:2330 .

21. Penninx BW, Milaneschi Y, Lamers F, Vogelzangs N. Understanding the somatic consequences of depression: biological mechanisms and the role of depression symptom profile. BMC Med 2013;11:129.

22. Wium-Andersen MK, Ørsted DD, Nielsen SF, Nordestgaard BG. Elevated C-reactive protein levels, psychological distress, and depression in 73, 131 individuals. JAMA Psychiatry 2013;70:176-184.

23. Leonard BE. Impact of inflammation on neurotransmitter changes in major depression: an insight into the action of antidepressants. Prog Neuropsychopharmacol Biol Psychiatry 2014;48:261-267.

24. Lasselin J, Capuron L. Chronic low-grade inflammation in metabolic disorders: relevance for behavioral symptoms. Neuroimmunomodulation 2014;21:95-101.

25. Berk M, Williams LJ, Jacka FN, O'Neil A, Pasco JA, Moylan S, et al. So depression is an inflammatory disease, but where does the inflammation come from? BMC Med 2013;11:200.

26. Heindel JJ, Balbus J, Birnbaum L, Brune-Drisse MN, Grandjean P, Gray K, et al. Developmental origins of 
health and disease: integrating environmental influences. Endocrinology 2015;156:3416-3421.

27. Heindel JJ, Vandenberg LN. Developmental origins of health and disease: a paradigm for understanding disease cause and prevention. Curr Opin Pediatr 2015;27:248-253.

28. David LA, Maurice CF, Carmody RN, Gootenberg DB, Button JE, Wolfe BE, et al. Diet rapidly and reproducibly alters the human gut microbiome. Nature 2014;505:559563.

29. Thaiss CA, Zeevi D, Levy M, Segal E, Elinav E. A day in the life of the meta-organism: diurnal rhythms of the intestinal microbiome and its host. Gut Microbes 2015;6: 137-142.

30. Lambert JE, Myslicki JP, Bomhof MR, Belke DD, Shearer $\mathrm{J}$, Reimer RA. Exercise training modifies gut microbiota in normal and diabetic mice. Appl Physiol Nutr Metab 2015;40:749-752.

31. Logan AC. Dysbiotic drift: mental health, environmental grey space, and microbiota. J Physiol Anthropol 2015;34: 23.

32. Ohland CL, Jobin C. Microbial activities and intestinal homeostasis: A delicate balance between health and disease. Cell Mol Gastroenterol Hepatol 2015;1:28-40.

33. Tuddenham S, Sears CL. The intestinal microbiome and health. Curr Opin Infect Dis 2015;28:464-470.

34. Sarris J, Logan AC, Akbaraly TN, Amminger GP, Balanzá-Martínez V, Freeman MP, et al; International Society for Nutritional Psychiatry Research. Nutritional medicine as mainstream in psychiatry. Lancet Psychiatry 2015;2:271-274.

35. Logan AC, Jacka FN. Nutritional psychiatry research: an emerging discipline and its intersection with global urbanization, environmental challenges and the evolutionary mismatch. J Physiol Anthropol 2014;33:22.

36. Dash S, Clarke G, Berk M, Jacka FN. The gut microbiome and diet in psychiatry: focus on depression. Curr Opin Psychiatry 2015;28:1-6.

37. Kohn D. When gut bacteria changes brain function [Internet]. The Atlantic; 2015 Jun 24 [cited at 2015 Aug 30]. Available from: http://www.theatlantic.com/health/archive/ 2015/06/gut-bacteria-on-the-brain/395918/

38. Schmidt C. Mental health: thinking from the gut. Nature 2015;518:S12-S15.

39. Reardon S. Gut-brain link grabs neuroscientists. Nature 2014;515:175-177.

40. Shen HH. News Feature: Microbes on the mind. Proc Natl Acad Sci U S A 2015;112:9143-9145.

41. Uwins D. Retrospect of the progress of medical science. London Med Reposit 1818;9:114.

42. Norman HJ. Lactic acid bacilli in the treatment of melancholia. Br Med J 1909;1:1234-1235.

43. Phillips JGP. The treatment of melancholia by the lactic acid bacillus. Br J Psychiatr 1910;56:422-431.

44. Editors of JAMA. Food and the control of bacteria in the intestine. JAMA 1919;72:1370.

45. Herter CA, Kendall AI. The influence of dietary alterations on the types of intestinal flora. J Biol Chem 1910;7: 203-236.

46. Morris RT. Surgery and its relation to the psychoses and the psychoneuroses. Trans Am Ther Soc 1919;1:100-102.

47. Bested AC, Logan AC, Selhub EM. Intestinal microbiota, probiotics and mental health: from Metchnikoff to modern advances: Part I - autointoxication revisited. Gut Pathog 2013;5:5.

48. Aminov RI. A brief history of the antibiotic era: lessons learned and challenges for the future. Front Microbiol 2010;1:134.

49. Halliday JL. Rising incidence of psychosomatic illness. Br Med $J$ 1938;2:11-14.

50. Lattey RM. Dr. Sigmund Freud, pseudoscientist. Can Fam Physician 1969;15:59-63.

51. Coppen A. The biochemistry of affective disorders. $\mathrm{Br} J$ Psychiatry 1967;113:1237-1264.

52. Dubos R, Schaedler RW. Some biological effects of the digestive flora. Am J Med Sci 1962;244:265-271.

53. Logan AC, Katzman MA, Balanzá-Martínez V. Natural environments, ancestral diets, and microbial ecology: is there a modern "paleo-deficit disorder"? Part II. J Physiol Anthropol 2015;34:9.

54. Lee CJ, Dubos R. Lasting biological effects of early environmental influences. 8. Effects of neonatal infection, perinatal malnutrition, and crowding on catecholamine metabolism of brain. J Exp Med 1972;136:1031-1042.

55. Goldman P. Therapeutic implications of the intestinal microflora. N Engl J Med 1973;289:623-628.

56. Bell IR, Jasnoski ML, Kagan J, King DS. Depression and allergies: survey of a nonclinical population. Psychother Psychosom 1991;55:24-31.

57. Strachan DP. Hay fever, hygiene, and household size. BMJ 1989;299:1259-1260.

58. Wold $\mathrm{AE}$. The hygiene hypothesis revised: is the rising frequency of allergy due to changes in the intestinal flora? Allergy 1998;53(46 Suppl):20-25.

59. Strannegård $\mathrm{O}$, Strannegård IL. The causes of the increasing prevalence of allergy: is atopy a microbial deprivation disorder? Allergy 2001;56:91-102.

60. Prescott SL. Disease prevention in the age of convergence - the need for a wider, long ranging and collaborative vision. Allergol Int 2014;63:11-20.

61. Weiss ST. Diet as a risk factor for asthma. Ciba Found Symp 1997;206:244-257.

62. Ellwood P, Asher MI, Björkstén B, Burr M, Pearce N, Robertson CF. Diet and asthma, allergic rhinoconjunctivitis and atopic eczema symptom prevalence: an ecological analysis of the International Study of Asthma and Allergies in Childhood (ISAAC) data. ISAAC Phase One Study Group. Eur Respir J 2001;17:436-443.

63. Björkstén B, Sepp E, Julge K, Voor T, Mikelsaar M. Allergy development and the intestinal microflora during the first year of life. J Allergy Clin Immunol 2001;108: 516-520.

64. Black PN, Sharpe S. Dietary fat and asthma: is there a connection? Eur Respir J 1997;10:6-12.

65. Sakai K, Okuyama H, Shimazaki H, Katagiri M, Torii S, Matsushita T, et al. Fatty acid compositions of plasma lipids in atopic dermatitis/asthma patients. Arerugi 1994; 43:37-43.

66. Bienenstock J, Wiley RE, Neigh GS, Waserman S, Keith P. Probiotics in the management and prevention of atopy. Clin Rev Allergy Immunol 2002;22:275-285.

67. Cross ML, Stevenson LM, Gill HS. Anti-allergy properties of fermented foods: an important immunoregulatory mechanism of lactic acid bacteria? Int Immunopharmacol 2001;1:891-901.

68. Sudo N, Yu XN, Aiba Y, Oyama N, Sonoda J, Koga Y, et al. An oral introduction of intestinal bacteria prevents the development of a long-term Th2-skewed immunological memory induced by neonatal antibiotic treatment in mice. Clin Exp Allergy 2002;32:1112-1116.

69. Logan AC, Venket Rao A, Irani D. Chronic fatigue 
syndrome: lactic acid bacteria may be of therapeutic value. Med Hypotheses 2003;60:915-923.

70. Butt HL, Dunstan RH, McGregor NR, Roberts TK. Bacterial colonosis in patients with persistent fatigue. In: Proceedings of the International Clinical and Scientific Meeting; Dec 1-2, 2001; Sydney, Australia. Sydney:Alison Hunter Memorial Foundation;2001

71. Gaykema RP, Goehler LE, Lyte M. Brain response to cecal infection with Campylobacter jejuni: analysis with Fos immunohistochemistry. Brain Behav Immun 2004;18:238245.

72. Wang X, Wang BR, Zhang XJ, Xu Z, Ding YQ, Ju G. Evidences for vagus nerve in maintenance of immune balance and transmission of immune information from gut to brain in STM-infected rats. World $J$ Gastroenterol 2002;8:540-545.

73. Reichenberg A, Yirmiya R, Schuld A, Kraus T, Haack M, Morag A, et al. Cytokine-associated emotional and cognitive disturbances in humans. Arch Gen Psychiatry 2001;58: 445-452.

74. Marston W. Leaky guts and disease. Newsweek. Nov 17, 1997.

75. Walker J, Dieleman L, Mah D, Park K, Meddings J, Vethanayagam D. High prevalence of abnormal gastrointestinal permeability in moderate-severe asthma. Clin Invest Med 2014;37:E53-E57.

76. Kalach N, Kapel N, Waligora-Dupriet AJ, Castelain MC, Cousin MO, Sauvage $\mathrm{C}$, et al. Intestinal permeability and fecal eosinophil-derived neurotoxin are the best diagnosis tools for digestive non-IgE-mediated cow's milk allergy in toddlers. Clin Chem Lab Med 2013;51:351-361.

77. Maes M, Kubera M, Leunis JC, Berk M. Increased IgA and IgM responses against gut commensals in chronic depression: further evidence for increased bacterial translocation or leaky gut. J Affect Disord 2012;141:55-62.

78. Maes M, Mihaylova I, Kubera M, Leunis JC. An IgMmediated immune response directed against nitro-bovine serum albumin (nitro-BSA) in chronic fatigue syndrome (CFS) and major depression: evidence that nitrosative stress is another factor underpinning the comorbidity between major depression and CFS. Neuro Endocrinol Lett 2008;29:313-319.

79. Swanson GR, Gorenz A, Shaikh M, Desai V, Forsyth C, Fogg L, et al. Decreased melatonin secretion is associated with increased intestinal permeability and marker of endotoxemia in alcoholics. Am J Physiol Gastrointest Liver Physiol 2015;308:G1004-G1011.

80. Gummesson A, Carlsson LM, Storlien LH, Bäckhed F, Lundin $\mathrm{P}$, Löfgren L, et al. Intestinal permeability is associated with visceral adiposity in healthy women. Obesity (Silver Spring) 2011;19:2280-2282.

81. Teixeira TF, Collado MC, Ferreira CL, Bressan J, Peluzio Mdo C. Potential mechanisms for the emerging link between obesity and increased intestinal permeability. Nutr Res 2012;32:637-647.

82. Goebel A, Buhner S, Schedel R, Lochs H, Sprotte G. Altered intestinal permeability in patients with primary fibromyalgia and in patients with complex regional pain syndrome. Rheumatology (Oxford) 2008;47:1223-1227.

83. Zuhl M, Schneider S, Lanphere K, Conn C, Dokladny K, Moseley P. Exercise regulation of intestinal tight junction proteins. Br J Sports Med 2014;48:980-986.

84. Vanuytsel T, van Wanrooy S, Vanheel H, Vanormelingen C, Verschueren S, Houben E, et al. Psychological stress and corticotropin-releasing hormone increase intestinal permeability in humans by a mast cell-dependent mechanism. Gut 2014;63:1293-1299.

85. Gárate I, García-Bueno B, Madrigal JL, Bravo L, Berrocoso E, Caso JR, et al. Origin and consequences of brain Toll-like receptor 4 pathway stimulation in an experimental model of depression. J Neuroinflammation 2011;8:151.

86. Madsen K, Cornish A, Soper P, McKaigney C, Jijon H, Yachimec $\mathrm{C}$, et al. Probiotic bacteria enhance murine and human intestinal epithelial barrier function. Gastroenterology 2001;121:580-591.

87. Naruszewicz M, Johansson ML, Zapolska-Downar D, Bukowska H. Effect of Lactobacillus plantarum 299v on cardiovascular disease risk factors in smokers. Am J Clin Nutr 2002;76:1249-1255.

88. Songisepp E, Kals J, Kullisaar T, Mändar R, Hütt P, Zilmer $\mathrm{M}$, et al. Evaluation of the functional efficacy of an antioxidative probiotic in healthy volunteers. Nutr $J$ $2005 ; 4: 22$.

89. Logan AC, Katzman M. Major depressive disorder: probiotics may be an adjuvant therapy. Med Hypotheses 2005; 64:533-538.

90. Sudo N, Chida Y, Aiba Y, Sonoda J, Oyama N, Yu XN, et al. Postnatal microbial colonization programs the hypothalamic-pituitary-adrenal system for stress response in mice. J Physiol 2004;558:263-275.

91. Hegstrand LR, Hine RJ. Variations of brain histamine levels in germ-free and nephrectomized rats. Neurochem Res 1986;11:185-191.

92. Markham A, Bains R, Franklin P, Spedding M. Changes in mitochondrial function are pivotal in neurodegenerative and psychiatric disorders: how important is BDNF? $\mathrm{Br} J$ Pharmacol 2014;171:2206-2229.

93. Bahi A, Schwed JS, Walter M, Stark H, Sadek B. Anxiolytic and antidepressant-like activities of the novel and potent non-imidazole histamine $\mathrm{H}_{3}$ receptor antagonist ST-1283. Drug Des Devel Ther 2014;8:627-637.

94. Trojan TD, Khan DA, Defina LF, Akpotaire O, Goodwin RD, Brown ES. Asthma and depression: the Cooper Center longitudinal study. Ann Allergy Asthma Immunol 2014;112:432-436.

95. Rank MA, Shah ND. Multiple chronic conditions and asthma: implications for practice and research. $J$ Allergy Clin Immunol Pract 2014;2:518-524.

96. Cheng TS, Chen H, Lee T, Teoh OH, Shek L, Lee BW, et al. An independent association of prenatal depression with wheezing and anxiety with rhinitis in infancy. Pediatr Allergy Immunol 2015;26:765-771.

97. Evans M, Barry M, Im Y, Brown A, Jason LA. An investigation of symptoms predating CFS onset. J Prev Interv Community 2015;43:54-61.

98. Jiang $\mathrm{H}$, Ling Z, Zhang $\mathrm{Y}$, Mao $\mathrm{H}$, Ma Z, Yin $\mathrm{Y}$, et al. Altered fecal microbiota composition in patients with major depressive disorder. Brain Behav Immun 2015;48:186-194.

99. Naseribafrouei A, Hestad K, Avershina E, Sekelja M, Linløkken A, Wilson R, et al. Correlation between the human fecal microbiota and depression. Neurogastroenterol Motil 2014;26:1155-1162.

100. Frémont M, Coomans D, Massart S, De Meirleir K. High-throughput $16 S$ rRNA gene sequencing reveals alterations of intestinal microbiota in myalgic encephalomyelitis/chronic fatigue syndrome patients. Anaerobe 2013;22:50-56.

101. Sheedy JR, Wettenhall RE, Scanlon D, Gooley PR, Lewis 
DP, McGregor N, et al. Increased d-lactic Acid intestinal bacteria in patients with chronic fatigue syndrome. In Vivo 2009;23:621-628.

102. Bisgaard H, Li N, Bonnelykke K, Chawes BL, Skov T, Paludan-Müller G, et al. Reduced diversity of the intestinal microbiota during infancy is associated with increased risk of allergic disease at school age. J Allergy Clin Immunol 2011;128:646-652.e1-5.

103. Abrahamsson TR, Jakobsson HE, Andersson AF, Björkstén B, Engstrand L, Jenmalm MC. Low gut microbiota diversity in early infancy precedes asthma at school age. Clin Exp Allergy 2014;44:842-850.

104. Prescott S, Allen KJ. Food allergy: riding the second wave of the allergy epidemic. Pediatr Allergy Immunol 2011;22: 155-160.

105. Ellwood P, Asher MI, García-Marcos L, Williams H, Keil U, Robertson C, et al; ISAAC Phase III Study Group. Do fast foods cause asthma, rhinoconjunctivitis and eczema? Global findings from the International Study of Asthma and Allergies in Childhood (ISAAC) phase three. Thorax 2013;68:351-360.

106. von Ehrenstein OS, Aralis H, Flores ME, Ritz B. Fast food consumption in pregnancy and subsequent asthma symptoms in young children. Pediatr Allergy Immunol 2015;26: 571-577.

107. McDade TW. Early environments and the ecology of inflammation. Proc Natl Acad Sci U S A 2012 6;109 Suppl 2:17281-17288

108. Rosenfeld CS. Microbiome disturbances and autism spectrum disorders. Drug Metab Dispos 2015;43:15571571.

109. Horrobin DF. Modern biomedical research: an internally self-consistent universe with little contact with medical reality? Nat Rev Drug Discov 2003;2:151-154.

110. Kirmayer LJ, Crafa D. What kind of science for psychiatry? Front Hum Neurosci 2014:8:435.

111. Rollin MD, Rollin BE. Crazy like a fox. Validity and ethics of animal models of human psychiatric disease. Camb $Q$ Healthc Ethics 2014;23:140-151.

112. Nguyen TL, Vieira-Silva S, Liston A, Raes J. How informative is the mouse for human gut microbiota research? Dis Model Mech 2015;8:1-16.

113. Bercik P, Park AJ, Sinclair D, Khoshdel A, Lu J, Huang $\mathrm{X}$, et al. The anxiolytic effect of Bifidobacterium longum NCC3001 involves vagal pathways for gut-brain communication. Neurogastroenterol Motil 2011;23:1132-1139.

114. Bravo JA, Forsythe P, Chew MV, Escaravage E, Savignac $\mathrm{HM}$, Dinan TG, et al. Ingestion of Lactobacillus strain regulates emotional behavior and central GABA receptor expression in a mouse via the vagus nerve. Proc Natl Acad Sci U S A 2011;108:16050-16055.

115. Dev S, Mizuguchi H, Das AK, Matsushita C, Maeyama K, Umehara $\mathrm{H}$, et al. Suppression of histamine signaling by probiotic Lac-B: a possible mechanism of its anti-allergic effect. J Pharmacol Sci 2008;107:159-166.

116. Jacome LF, Burket JA, Herndon AL, Deutsch SI. Genetically inbred Balb/c mice differ from outbred Swiss Webster mice on discrete measures of sociability: relevance to a genetic mouse model of autism spectrum disorders. Autism Res 2011;4:393-400.

117. Brinks V, van der Mark M, de Kloet R, Oitzl M. Emotion and cognition in high and low stress sensitive mouse strains: a combined neuroendocrine and behavioral study in BALB/c and C57BL/6J mice. Front Behav Neurosci 2007;1:8.
118. Bercik P, Denou E, Collins J, Jackson W, Lu J, Jury J, et al. The intestinal microbiota affect central levels of brain-derived neurotropic factor and behavior in mice. Gastroenterology 2011;141:599-609.

119. Ait-Belgnaoui A, Colom A, Braniste V, Ramalho L, Marrot $\mathrm{A}$, Cartier C, et al. Probiotic gut effect prevents the chronic psychological stress-induced brain activity abnormality in mice. Neurogastroenterol Motil 2014;26:510-520.

120. Erdman SE, Poutahidis T. Probiotic 'glow of health': it's more than skin deep. Benef Microbes 2014;5:109-119.

121. Gannon RL. Non-peptide oxytocin receptor ligands and hamster circadian wheel running rhythms. Brain Res 2014;1585:184-190.

122. Zhang G, Cai D. Circadian intervention of obesity development via resting-stage feeding manipulation or oxytocin treatment. Am J Physiol Endocrinol Metab 2011;301:E1004-E1012.

123. Welch MG, Margolis KG, Li Z, Gershon MD. Oxytocin regulates gastrointestinal motility, inflammation, macromolecular permeability, and mucosal maintenance in mice. Am J Physiol Gastrointest Liver Physiol 2014;307:G848G862.

124. Hofmann SG, Fang A, Brager DN. Effect of intranasal oxytocin administration on psychiatric symptoms: A metaanalysis of placebo-controlled studies. Psychiatry Res 2015;228:708-714.

125. Patel N, Grillon C, Pavletic N, Rosen D, Pine DS, Ernst M. Oxytocin and vasopressin modulate risk-taking. Physiol Behav 2015;139:254-260.

126. Bruce-Keller AJ, Salbaum JM, Luo M, Blanchard E 4th, Taylor CM, Welsh DA, et al. Obese-type gut microbiota induce neurobehavioral changes in the absence of obesity. Biol Psychiatry 2015;77:607-615.

127. Erny D, Hrabě de Angelis AL, Jaitin D, Wieghofer P, Staszewski O, David E, et al. Host microbiota constantly control maturation and function of microglia in the CNS. Nat Neurosci 2015;18:965-977.

128. Frost G, Sleeth ML, Sahuri-Arisoylu M, Lizarbe B, Cerdan $\mathrm{S}$, Brody $\mathrm{L}$, et al. The short-chain fatty acid acetate reduces appetite via a central homeostatic mechanism. Nat Commun 2014;5:3611.

129. Yang H, Zhao X, Tang S, Huang H, Zhao X, Ning Z, et al. Probiotics reduce psychological stress in patients before laryngeal cancer surgery. Asia Pac J Clin Oncol 2016; 21:e92-e96.

130. Benton D, Williams C, Brown A. Impact of consuming a milk drink containing a probiotic on mood and cognition. Eur J Clin Nutr 2007;61:355-361.

131. Rao AV, Bested AC, Beaulne TM, Katzman MA, Iorio C, Berardi JM, et al. A randomized, double-blind, placebocontrolled pilot study of a probiotic in emotional symptoms of chronic fatigue syndrome. Gut Pathog 2009;1:6.

132. Messaoudi M, Lalonde R, Violle N, Javelot H, Desor D, Nejdi A, et al. Assessment of psychotropic-like properties of a probiotic formulation (Lactobacillus helveticus R0052 and Bifidobacterium longum R0175) in rats and human subjects. Br J Nutr 2011;105:755-764.

133. Messaoudi M, Violle N, Bisson JF, Desor D, Javelot H, Rougeot C. Beneficial psychological effects of a probiotic formulation (Lactobacillus helveticus R0052 and Bifidobacterium longum R0175) in healthy human volunteers. Gut Microbes 2011;2:256-261.

134. Sashihara T, Nagata M, Mori T, Ikegami S, Gotoh M, Okubo K, et al. Effects of Lactobacillus gasseri OLL2809 and a-lactalbumin on university-student athletes: a 
randomized, double-blind, placebo-controlled clinical trial. Appl Physiol Nutr Metab 2013;38:1228-1235.

135. Pärtty A, Kalliomäki M, Wacklin P, Salminen S, Isolauri E. A possible link between early probiotic intervention and the risk of neuropsychiatric disorders later in childhood: a randomized trial. Pediatr Res 2015;77:823-828.

136. Steenbergen L, Sellaro R, van Hemert S, Bosch JA, Colzato LS. A randomized controlled trial to test the effect of multispecies probiotics on cognitive reactivity to sad mood. Brain Behav Immun 2015;48:258-264.

137. Owen L, Reinders M, Narramore R, Marsh AMR, Lui F, Baron $\mathrm{R}$, et al. A double-blind, placebo-controlled, randomized pilot trial examining the effects of probiotic administration on mood and cognitive function. Proc Nutr Soc 2014;73:E29.

138. Nishihara J, Kagami-Katsuyama H, Tanaka A, Nishimura M, Kobayashi T, Kawasaki Y. Elevation of natural killer cell activity and alleviation of mental stress by the consumption of yogurt containing Lactobacillus gasseri SBT2055 and Bifidobacterium longum SBT2928 in a double-blind, placebo-controlled clinical trial. J Funct Food 2014;11:261-268.

139. Tillisch K, Labus J, Kilpatrick L, Jiang Z, Stains J, Ebrat $\mathrm{B}$, et al. Consumption of fermented milk product with probiotic modulates brain activity. Gastroenterology 2013;144:1394-1401, 1401.e1-4.

140. O'Brien ME, Anderson H, Kaukel E, O’Byrne K, Pawlicki M, Von Pawel J, et al; SR-ON-12 Study Group. SRL172 (killed Mycobacterium vaccae) in addition to standard chemotherapy improves quality of life without affecting survival, in patients with advanced non-small-cell lung cancer: phase III results. Ann Oncol 2004;15:906-914.

141. Lorenzo-Zúñiga V, Llop E, Suárez C, Alvarez B, Abreu L, Espadaler J, et al. I.31, a new combination of probiotics, improves irritable bowel syndrome-related quality of life. World J Gastroenterol 2014;20:8709-8716.

142. Lee JY, Chu SH, Jeon JY, Lee MK, Park JH, Lee DC, et al. Effects of 12 weeks of probiotic supplementation on quality of life in colorectal cancer survivors: a doubleblind, randomized, placebo-controlled trial. Dig Liver Dis 2014;46:1126-1132.

143. Kaplan BJ, Rucklidge JJ, Romijn R, McLeod K. The emerging field of nutritional mental health: inflammation, the microbiome, oxidative stress, and mitochondrial function. Clin Psychol Sci 2015. doi: 10.1177/2167702614555413 [Epub ahead of print]

144. Jacka FN, Mykletun A, Berk M, Bjelland I, Tell GS. The association between habitual diet quality and the common mental disorders in community-dwelling adults: the Hordaland Health study. Psychosom Med 2011;73:483-490.

145. Jacka FN, Pasco JA, Mykletun A, Williams LJ, Hodge AM, O'Reilly SL, et al. Association of Western and traditional diets with depression and anxiety in women. Am J Psychiatry 2010;167:305-311.

146. Sánchez-Villegas A, Delgado-Rodríguez M, Alonso A, Schlatter J, Lahortiga F, Serra Majem L, et al. Association of the Mediterranean dietary pattern with the incidence of depression: the Seguimiento Universidad de Navarral University of Navarra follow-up (SUN) cohort. Arch Gen Psychiatry 2009;66:1090-1098.

147. Skarupski KA, Tangney CC, Li H, Evans DA, Morris MC Mediterranean diet and depressive symptoms among older adults over time. J Nutr Health Aging 2013;17:441-445.

148. Rienks J, Dobson AJ, Mishra GD. Mediterranean dietary pattern and prevalence and incidence of depressive symptoms in mid-aged women: results from a large community-based prospective study. Eur J Clin Nutr 2013;67:75-82.

149. Lee J, Pase M, Pipingas A, Raubenheimer J, Thurgood M, Villalon L, et al. Switching to a 10-day Mediterranean-style diet improves mood and cardiovascular function in a controlled crossover study. Nutrition 2015;31:647-652.

150. McMillan L, Owen L, Kras M, Scholey A. Behavioural effects of a 10-day Mediterranean diet. Results from a pilot study evaluating mood and cognitive performance. Appetite 2011;56:143-147.

151. Steenbruggen TG, Hoekstra SJ, van der Gaag EJ. Could a change in diet revitalize children who suffer from unresolved fatigue? Nutrients 2015;7:1965-1977.

152. Rampelli S, Schnorr SL, Consolandi C, Turroni S, Severgnini M, Peano C, et al. Metagenome sequencing of the Hadza Hunter-Gatherer gut microbiota. Curr Biol 2015;25:1682-1693.

153. De Filippo C, Cavalieri D, Di Paola M, Ramazzotti M, Poullet JB, Massart S, et al. Impact of diet in shaping gut microbiota revealed by a comparative study in children from Europe and rural Africa. Proc Natl Acad Sci U S A 2010;107:14691-14696.

154. Obregon-Tito AJ, Tito RY, Metcalf J, Sankaranarayanan K, Clemente JC, Ursell LK, et al. Subsistence strategies in traditional societies distinguish gut microbiomes. Nat Commun 2015;6:6505.

155. Martínez I, Stegen JC, Maldonado-Gómez MX, Eren AM, Siba PM, Greenhill AR, et al. The gut microbiota of rural papua new guineans: composition, diversity patterns, and ecological processes. Cell Rep 2015;11:527-538.

156. Yatsunenko T, Rey FE, Manary MJ, Trehan I, DominguezBello MG, Contreras M, et al. Human gut microbiome viewed across age and geography. Nature 2012;486:222227.

157. Clemente JC, Pehrsson EC, Blaser MJ, Sandhu K, Gao Z, Wang $\mathrm{B}$, et al. The microbiome of uncontacted Amerindians. Sci Adv 2015;1:e1500183.

158. Cotillard A, Kennedy SP, Kong LC, Prifti E, Pons N, Le Chatelier E, et al. Dietary intervention impact on gut microbial gene richness. Nature 2013;500:585-588.

159. Doré J, Blottière H. The influence of diet on the gut microbiota and its consequences for health. Curr Opin Biotechnol 2015;32:195-199.

160. Cordain L, Eaton SB, Sebastian A, Mann N, Lindeberg S, Watkins BA, et al. Origins and evolution of the Western diet: health implications for the 21st century. Am J Clin Nutr 2005;81:341-354.

161. Yang Y, Zheng L, Wang L, Wang S, Wang Y, Han Z. Effects of high fructose and salt feeding on systematic metabonome probed via (1) H NMR spectroscopy. Magn Reson Chem 2015;53:295-303.

162. Seiquer I, Rubio LA, Peinado MJ, Delgado-Andrade C, Navarro MP. Maillard reaction products modulate gut microbiota composition in adolescents. Mol Nutr Food Res 2014;58:1552-1560.

163. Chassaing B, Koren O, Goodrich JK, Poole AC, Srinivasan $\mathrm{S}$, Ley RE, et al. Dietary emulsifiers impact the mouse gut microbiota promoting colitis and metabolic syndrome. Nature 2015;519:92-96.

164. Cao ZJ, Yu JC, Kang WM, Ma ZQ, Ye X, Tian SB. Effect of $n-3$ polyunsaturated fatty acids on gut microbiota and endotoxin levels in portal vein of rats fed with high-fat diet. Zhongguo Yi Xue Ke Xue Yuan Xue Bao 2014;36:496-500.

165. Leclercq S, Matamoros S, Cani PD, Neyrinck AM, Jamar $\mathrm{F}$, Stärkel $\mathrm{P}$, et al. Intestinal permeability, gut-bacterial 
dysbiosis, and behavioral markers of alcohol-dependence severity. Proc Natl Acad Sci U S A 2014;111:E4485E4493.

166. Jahani R, Fielding KA, Chen J, Villa CR, Castelli LM, Ward WE, et al. Low vitamin D status throughout life results in an inflammatory prone status but does not alter bone mineral or strength in healthy 3-month-old CD-1 male mice. Mol Nutr Food Res 2014;58:1491-1501.

167. Assa A, Vong L, Pinnell LJ, Avitzur N, Johnson-Henry $\mathrm{KC}$, Sherman PM. Vitamin $D$ deficiency promotes epithelial barrier dysfunction and intestinal inflammation. J Infect Dis 2014;210:1296-1305.

168. Trebatická J, Duračková Z. Psychiatric disorders and polyphenols: Can they be helpful in therapy? Oxid Med Cell Longev 2015;2015:248529.

169. Haider S, Naqvi F, Batool Z, Tabassum S, Sadir S, Liaquat $\mathrm{L}$, et al. Pretreatment with curcumin attenuates anxiety while strengthens memory performance after one short stress experience in male rats. Brain Res Bull 2015;115:1-8.

170. Bouayed J, Rammal H, Dicko A, Younos C, Soulimani R. Chlorogenic acid, a polyphenol from Prunus domestica (Mirabelle), with coupled anxiolytic and antioxidant effects. J Neurol Sci 2007;262:77-84.

171. Solanki N, Alkadhi I, Atrooz F, Patki G, Salim S. Grape powder prevents cognitive, behavioral, and biochemical impairments in a rat model of posttraumatic stress disorder. Nutr Res 2015;35:65-75.

172. Pham NM, Nanri A, Kurotani K, Kuwahara K, Kume A, Sato $\mathrm{M}$, et al. Green tea and coffee consumption is inversely associated with depressive symptoms in a Japanese working population. Public Health Nutr 2014;17:625-633.

173. Sathyapalan T, Beckett S, Rigby AS, Mellor DD, Atkin SL. High cocoa polyphenol rich chocolate may reduce the burden of the symptoms in chronic fatigue syndrome. Nutr J 2010;9:55.

174. Pase MP, Scholey AB, Pipingas A, Kras M, Nolidin K, Gibbs A, et al. Cocoa polyphenols enhance positive mood states but not cognitive performance: a randomized, placebo-controlled trial. J Psychopharmacol 2013;27:451458.

175. Yu JJ, Pei LB, Zhang Y, Wen ZY, Yang JL. Chronic supplementation of curcumin enhances the efficacy of antidepressants in major depressive disorder: A randomized, double-blind, placebo-controlled pilot study. J Clin Psychopharmacol 2015;35:406-410.

176. Seo DB, Jeong HW, Cho D, Lee BJ, Lee JH, Choi JY, et al. Fermented green tea extract alleviates obesity and related complications and alters gut microbiota composition in diet-induced obese mice. J Med Food 2015;18:549-556.

177. Mills CE, Tzounis X, Oruna-Concha MJ, Mottram DS, Gibson GR, Spencer JP. In vitro colonic metabolism of coffee and chlorogenic acid results in selective changes in human faecal microbiota growth. Br J Nutr 2015;113: 1220-1227.

178. Massot-Cladera M, Pérez-Berezo T, Franch A, Castell M, Pérez-Cano FJ. Cocoa modulatory effect on rat faecal microbiota and colonic crosstalk. Arch Biochem Biophys 2012;527:105-112.

179. McFadden RM, Larmonier CB, Shehab KW, Midura-Kiela $\mathrm{M}$, Ramalingam $\mathrm{R}$, Harrison $\mathrm{CA}$, et al. The role of curcumin in modulating colonic microbiota during colitis and colon cancer prevention. Inflamm Bowel Dis 2015;21:2483-2494.

180. Gasperotti M, Passamonti S, Tramer F, Masuero D, Guella
G, Mattivi F, et al. Fate of microbial metabolites of dietary polyphenols in rats: is the brain their target destination? ACS Chem Neurosci 2015;6:1341-1352.

181. Parkar SG, Trower TM, Stevenson DE. Fecal microbial metabolism of polyphenols and its effects on human gut microbiota. Anaerobe 2013;23:12-19.

182. Kelly CJ, Colgan SP, Frank DN. Of microbes and meals: the health consequences of dietary endotoxemia. Nutr Clin Pract 2012;27:215-225.

183. Ghanim H, Sia CL, Upadhyay M, Korzeniewski K, Viswanathan $\mathrm{P}$, Abuaysheh $\mathrm{S}$, et al. Orange juice neutralizes the proinflammatory effect of a high-fat, highcarbohydrate meal and prevents endotoxin increase and Toll-like receptor expression. Am J Clin Nutr 2010;91: 940-949.

184. Carrasco-Pozo C, Morales P, Gotteland M. Polyphenols protect the epithelial barrier function of Caco-2 cells exposed to indomethacin through the modulation of occludin and zonula occludens-1 expression. J Agric Food Chem 2013;61:5291-5297.

185. Contreras TC, Ricciardi E, Cremonini E, Oteiza PI. (-)-Epicatechin in the prevention of tumor necrosis alpha-induced loss of Caco-2 cell barrier integrity. Arch Biochem Biophys 2015;573:84-91.

186. Ghosh SS, Bie J, Wang J, Ghosh S. Oral supplementation with non-absorbable antibiotics or curcumin attenuates western diet-induced atherosclerosis and glucose intolerance in LDLR-/- mice--role of intestinal permeability and macrophage activation. PLoS One 2014;9:e108577.

187. Kaliannan K, Wang B, Li XY, Kim KJ, Kang JX. $A$ host-microbiome interaction mediates the opposing effects of omega-6 and omega-3 fatty acids on metabolic endotoxemia. Sci Rep 2015;5:11276.

188. Su KP, Matsuoka Y, Pae CU. Omega-3 polyunsaturated fatty acids in prevention of mood and anxiety disorders. Clin Psychopharmacol Neurosci 2015;13:129-137.

189. Palmer DJ, Sullivan T, Gold MS, Prescott SL, Heddle R, Gibson RA, et al. Effect of n-3 long chain polyunsaturated fatty acid supplementation in pregnancy on infants' allergies in first year of life: randomised controlled trial. BMJ 2012;344:e184.

190. Blasbalg TL, Hibbeln JR, Ramsden CE, Majchrzak SF, Rawlings RR. Changes in consumption of omega-3 and omega- 6 fatty acids in the United States during the 20th century. Am J Clin Nutr 2011;93:950-962.

191. Alvarez-Suarez JM, Giampieri F, Battino M. Honey as a source of dietary antioxidants: structures, bioavailability and evidence of protective effects against human chronic diseases. Curr Med Chem 2013;20:621-638.

192. Azman KF, Zakaria R, AbdAziz C, Othman Z, Al-Rahbi B. Tualang honey improves memory performance and decreases depressive-like behavior in rats exposed to loud noise stress. Noise Health 2015;17:83-89.

193. Mijanur Rahman M, Gan SH, Khalil MI. Neurological effects of honey: current and future prospects. Evid Based Complement Alternat Med 2014;2014:958721.

194. Candiracci M, Piatti E, Dominguez-Barragán M, GarcíaAntrás D, Morgado B, Ruano D, et al. Anti-inflammatory activity of a honey flavonoid extract on lipopolysaccharideactivated N13 microglial cells. J Agric Food Chem 2012;60:12304-12311.

195. Ezz El-Arab AM, Girgis SM, Hegazy EM, Abd El-Khalek AB. Effect of dietary honey on intestinal microflora and toxicity of mycotoxins in mice. BMC Complement Altern Med 2006;6:6. 
196. Sanz ML, Polemis N, Morales V, Corzo N, Drakoularakou $\mathrm{A}$, Gibson GR, et al. In vitro investigation into the potential prebiotic activity of honey oligosaccharides. J Agric Food Chem 2005;53:2914-2921.

197. Miki T, Kochi T, Eguchi M, Kuwahara K, Tsuruoka H, Kurotani $\mathrm{K}$, et al. Dietary intake of minerals in relation to depressive symptoms in Japanese employees: the Furukawa Nutrition and Health Study. Nutrition 2015;31:686-690.

198. Pyndt Jørgensen B, Winther G, Kihl P, Nielsen DS, Wegener G, Hansen AK, et al. Dietary magnesium deficiency affects gut microbiota and anxiety-like behaviour in C57BL/6N mice. Acta Neuropsychiatr 2015;27:307-311.

199. Winther G, Pyndt Jørgensen BM, Elfving B, Nielsen DS, Kihl $\mathrm{P}$, Lund $\mathrm{S}$, et al. Dietary magnesium deficiency alters gut microbiota and leads to depressive-like behaviour. Acta Neuropsychiatr 2015;27:168-176.

200. Gao F, Ding B, Zhou L, Gao X, Guo H, Xu H. Magnesium sulfate provides neuroprotection in lipopolysaccharideactivated primary microglia by inhibiting $N F-\kappa B$ pathway. J Surg Res 2013;184:944-950.

201. Obata Y, Furusawa Y, Hase K. Epigenetic modifications of the immune system in health and disease. Immunol Cell Biol 2015;93:226-232.

202. Gao Y, Tollefsbol TO. Impact of epigenetic dietary components on cancer through histone Modifications. Curr Med Chem 2015;22:2051-2064.

203. Hanson MA, Gluckman PD. Early developmental conditioning of later health and disease: physiology or pathophysiology? Physiol Rev 2014;94:1027-1076.

204. Jacka FN, Ystrom E, Brantsaeter AL, Karevold E, Roth C, Haugen $\mathrm{M}$, et al. Maternal and early postnatal nutrition and mental health of offspring by age 5 years: a prospective cohort study. J Am Acad Child Adolesc Psychiatry 2013;52:1038-1047.

205. DeVries A, Vercelli D. Early predictors of asthma and allergy in children: the role of epigenetics. Curr Opin Allergy Clin Immunol 2015;15:435-439.

206. Kubota T, Miyake K, Hariya N, Mochizuki K. Understanding the epigenetics of neurodevelopmental disorders and DOHaD. J Dev Orig Health Dis 2015;6:96-104.

207. Zhao D, Su H, Cheng J, Wang X, Xie M, Li K, et al. Prenatal antibiotic use and risk of childhood wheeze/ asthma: A meta-analysis. Pediatr Allergy Immunol 2015, 26:756-764.

208. Mueller NT, Whyatt R, Hoepner L, Oberfield S, Dominguez-Bello MG, Widen EM, et al. Prenatal exposure to antibiotics, cesarean section and risk of childhood obesity. Int J Obes (Lond) 2015;39:665-670.

209. Tsai PT, Greene-Colozzi E, Goto J, Anderl S, Kwiatkowski DJ, Sahin M. Prenatal rapamycin results in early and late behavioral abnormalities in wildtype C57BL/6 mice. Behav Genet 2013;43:51-59.

210. Ilgin S, Can OD, Atli O, Ucel UI, Sener E, Guven I. Ciprofloxacin-induced neurotoxicity: evaluation of possible underlying mechanisms. Toxicol Mech Methods 2015;25. 374-381.

211. Wang $\mathrm{T}, \mathrm{Hu} \mathrm{X}$, Liang $\mathrm{S}, \mathrm{Li} \mathrm{W}, \mathrm{Wu} \mathrm{X}$, Wang $\mathrm{L}$, et al. Lactobacillus fermentum NS9 restores the antibiotic induced physiological and psychological abnormalities in rats. Benef Microbes 2015;6:707-717.

212. Dinan TG, Stanton C, Cryan JF. Psychobiotics: a novel class of psychotropic. Biol Psychiatry 2013;74:720-726.

213. Inoue $\mathrm{Y}$, Kambara $\mathrm{T}$, Murata $\mathrm{N}$, Komori-Yamaguchi J, Matsukura S, Takahashi Y, et al. Effects of oral administration of Lactobacillus acidophilus L-92 on the symptoms and serum cytokines of atopic dermatitis in Japanese adults: a double-blind, randomized, clinical trial. Int Arch Allergy Immunol 2014;165:247-254.

214. Miyazawa K, Kawase M, Kubota A, Yoda K, Harata G, Hosoda M, et al. Heat-killed Lactobacillus gasseri can enhance immunity in the elderly in a double-blind, placebocontrolled clinical study. Benef Microbes 2015;6:441-449.

215. Asama T, Arima TH, Gomi T, Keishi T, Tani H, Kimura $\mathrm{Y}$, et al. Lactobacillus kunkeei YB38 from honeybee products enhances IgA production in healthy adults. $J$ Appl Microbiol 2015;119:818-826.

216. Harima-Mizusawa N, lino T, Onodera-Masuoka N, KatoNagaoka N, Kiyoshima-Shibata J, Gomi A, et al. Beneficial effects of citrus juice fermented with Lactobacillus plantarum YIT 0132 on Japanese cedar pollinosis. Biosci Microbiota Food Health 2014;33:147-155.

217. Bouladoux N, Hall JA, Grainger JR, dos Santos LM, Kann MG, Nagarajan V, et al. Regulatory role of suppressive motifs from commensal DNA. Mucosal Immunol 2012;5: 623-634.

218. Jijon H, Backer J, Diaz H, Yeung H, Thiel D, McKaigney $\mathrm{C}$, et al. DNA from probiotic bacteria modulates murine and human epithelial and immune function. Gastroenterology 2004;126:1358-1373.

219. Jensen MP, Meldrum S, Taylor AL, Dunstan JA, Prescott SL. Early probiotic supplementation for allergy prevention: long-term outcomes. J Allergy Clin Immunol 2012;130: 1209-1211.e5.

220. West CE, Jenmalm MC, Prescott SL. The gut microbiota and its role in the development of allergic disease: a wider perspective. Clin Exp Allergy 2015;45:43-53.

221. Elazab N, Mendy A, Gasana J, Vieira ER, Quizon A, Forno E. Probiotic administration in early life, atopy, and asthma: a meta-analysis of clinical trials. Pediatrics 2013;132: e666-e676

222. Simpson MR, Dotterud CK, Storrø O, Johnsen R, Øien T. Perinatal probiotic supplementation in the prevention of allergy related disease: 6 year follow up of a randomised controlled trial. BMC Dermatol 2015;15:13.

223. Ridaura VK, Faith JJ, Rey FE, Cheng J, Duncan AE, Kau $\mathrm{AL}$, et al. Gut microbiota from twins discordant for obesity modulate metabolism in mice. Science 2013;341:1241214.

224. Duca FA, Sakar Y, Lepage P, Devime F, Langelier B, Doré $\mathrm{J}$, et al. Replication of obesity and associated signaling pathways through transfer of microbiota from obese-prone rats. Diabetes 2014;63:1624-1636.

225. Selhub EM, Logan AC, Bested AC. Fermented foods, microbiota, and mental health: ancient practice meets nutritional psychiatry. J Physiol Anthropol 2014;33:2.

226. Hilimire MR, DeVylder JE, Forestell CA. Fermented foods, neuroticism, and social anxiety: An interaction model. Psychiatry Res 2015:228:203-208.

227. Hesselmar B, Hicke-Roberts A, Wennergren G. Allergy in children in hand versus machine dishwashing. Pediatrics 2015;135:e590-e597.

228. Yang HL, Xia HQ, Ye YD, Zou WC, Sun YZ. Probiotic Bacillus pumilus SE5 shapes the intestinal microbiota and mucosal immunity in grouper Epinephelus coioides. Dis Aquat Organ 2014;111:119-127.

229. Vitali B, Minervini G, Rizzello CG, Spisni E, Maccaferri $\mathrm{S}$, Brigidi $\mathrm{P}$, et al. Novel probiotic candidates for humans isolated from raw fruits and vegetables. Food Microbiol 2012:31:116-125.

230. Lang JM, Eisen JA, Zivkovic AM. The microbes we eat: abundance and taxonomy of microbes consumed in a day's 
worth of meals for three diet types. PeerJ 2014;2:e659.

231. Nukina H, Sudo N, Aiba Y, Oyama N, Koga Y, Kubo C. Restraint stress elevates the plasma interleukin-6 levels in germ-free mice. J Neuroimmunol 2001;115:46-52.

232. Fleissner CK, Huebel N, Abd El-Bary MM, Loh G, Klaus $\mathrm{S}$, Blaut M. Absence of intestinal microbiota does not protect mice from diet-induced obesity. $\mathrm{Br} J$ Nutr 2010;104:919-929.

233. van den Nieuwboer M, Brummer RJ, Guarner F, Morelli L, Cabana M, Claassen E. Safety of probiotics and synbiotics in children under 18 years of age. Benef Microbes 2015;6:615-630.
234. Koller MM, Maeda N, Scarpace PJ, Humphreys-Beher MG. Desipramine changes salivary gland function, oral microbiota, and oral health in rats. Eur $J$ Pharmacol 2000;408:91-98.

235. Palmer DJ, Huang RC, Craig JM, Prescott SL. Nutritional influences on epigenetic programming: asthma, allergy, and obesity. Immunol Allergy Clin North Am 2014;34: 825-837.

236. Chilton SN, Burton JP, Reid G. Inclusion of fermented foods in food guides around the world. Nutrients 2015;7:390-404. 